\title{
Factual Problems of Detection, Fixing, and Keeping Large Territorial Objects of Historial and Cultural Heritage
}

\author{
Eleonora Shevtchenko ${ }^{1, *}$
}

\author{
${ }^{1}$ Scientific Research Institute of the Theory and History of Architecture and Urban Planning, Branch of the \\ Federal State Budget Institution "Central Scientific-Research and Project Institute of the Construction Ministry \\ of Russia", Moscow, Russia \\ *Corresponding author. Email: shegal1948@mail.ru
}

\begin{abstract}
Detection of a certain strictly located volumetric-spatial and planning integrity characterized as a historical settlement or a landmark on the territory of a modern city or town is a serious problem. Its essence lies in the vagueness of the such concepts as 'historical settlement' and 'landmark', mentioned in the currently existing federal law "On the Objects of Cultural Heritage (Monuments of History and Culture) of the Peoples of the Russian Federation" No. 73-FZ (Federal Law) of June 25, 2002. The uncertainty and ambiguity of terms of 'the object of protection' of historical settlement and various landmarks also make the situation more complicated, and in some cases clear localization of such unique objects as 'historical settlement' and 'landmark' is impossible. The article presents a problem of localization and volumetric-spatial and planning integrity of historical settlements and landmarks. The author argues that the basic fact for identification of a historical settlement on the territory of a contemporary city or town is the existence of historical milieu - even in the case when any objects of cultural heritage are absent. It is necessary to correct the terms and formulas of the law on such objects because of recognition of the intangible reality of previous epochs materialized as the most valuable asset.
\end{abstract}

Keywords: Historical settlement, Landmark, Collisions of legislation, Problems of detection and fixing of objects.

\section{INTRODUCTION}

Detection of a certain strictly located volumetric-spatial and planning integrity characterized as a historical settlement or a landmark on the territory of a modern city or town is a serious problem. Even more difficult is the problem of identifying and fixing such objects of cultural heritage as landmarks. The essence of the problem lies in the vagueness of the such concepts as 'historical settlement' and 'landmark', mentioned in the currently existing federal law "On the Objects of Cultural Heritage (Monuments of

*Fund: This study is based on the research, supported by the Program of Fundamental Research of the Russian Academy of Architecture and Construction Sciences and of the Ministry of Construction, Housing and Utilities of the Russian Federation 2021.
History and Culture) of the Peoples of the Russian Federation" No. 73-FZ (Federal Law) of June 25, 2002. The current "Methodological recommendations for assessing the historical and cultural value of a settlement" [1] do not solve this problem - that is understandable, because they use only the concept adopted in the legislative act that does not allow interpretations contradicting the law. However, if in the "Methodological recommendations for assessing the historical and cultural value of a settlement" an attempt is made to reveal the actual spiritual value of the localized object, in the "Methodological recommendations for classifying historical and cultural territories as objects of cultural heritage in the form of a landmark" (the work have not been completed) the types of landmarks specified in the federal law are taken for granted, which makes it almost 
impossible to identify and fix such unique objects of cultural heritage.

\section{HISTORICAL SETTLEMENT}

Based on the terms of the federal law, the key points which allow to define a town or a city 'historical settlement' include the following ones: existing some objects of cultural heritage enlisted in the register (the United State Register of the Objects of Cultural Heritage), as well as found objects of cultural heritage described by experts. Along with it, they have to indicate some 'objects' which are under the local protection.

At that, the law does not state that all named objects must be localized in a limited area and represent a certain volumetric-spatial and planning integrity that gives an idea of the settlement of the previous period and, most importantly, corresponds to the concept of 'settlement'. That is, the formality is set as the dominant in the law - the presence of real estate objects of history and culture, not the fact of purposeful formation of any socially determined object in a certain time interval in the past.

In 2010, at a meeting of the ICOMOS International Research Committee on Historic Cities and Rural Areas, a document was drawn up on the attitude towards the problem of such settlements, which declared an idea that the historic city is firmly rooted in its environment. However, it should be stated that the environment that surrounded a settlement in the periods from its foundation and initial construction up to the present has undergone significant changes. The phrase "the settlement is rooted" should be applied exclusively to the landscape peculiarities of the area, and even then, in some cases only, because that very pristine place where the city 'was born' usually has not survived. It is a natural consequence of the development of settlements, accompanied by the growth of built-up areas, changes in their landscape, its transformation, leading, in practice, to the destruction of the natural environment. Today, the natural surroundings of a historical settlement could be created in the twentieth century, taking the place of once natural environment. However, it does not mean that the loss of such environment or traces of the 'rootedness' in it will inevitably lead to the loss of a certain material and non-material reality, called 'historical settlement'. That is, we can talk about identifying the fact of the development of urban planning culture ${ }^{1}$. The phrase, first introduced in 1985 by E.A. Goldsamt and O.A. Shvidkovsky, practically marked the beginning of a new understanding of the value of the city, offering a 'road' to correctly identifying the most valuable for the peoples of the Russian Federation asset in the form of the intangible reality [2]. In this context, it is the 'city' that is of the greatest interest and value because it is the 'City', as many researchers believed - N.P. Antsiferov, for instance; it is a 'quintessence of culture', its material expression, directly depending on time.

What, at present, can provide primary information about the preserved historical intangible reality, is the planning structure of a settlement that clearly and unambiguously locating - outlining the space of the settlement - in which the material traces of its historical development are preserved. In this regard, it is necessary to find out what role the certain settlement played in the historical development of the state, its role in the historical settlement system and the influence of these factors on the spatial planning development and the historical functional use of territories.

It is necessary to establish as reliably as possible the historical settlement that represents for contemporaries and future generations - an enduring spiritual, scientific, aesthetic and, therefore, emotional, artistic, material, and other value. Noteworthy, the primary source of information is a collection of the first master plans of cities and towns confirmed by Empress Catherine the Great. The layout that has survived by nowadays on the territory of a settlement should be considered as the main indicator of its most ancient territory, developed by previous generations. It is the territory that is the most valuable in historical context, requiring the most stringent measures for urban restoration (reconstruction). The purpose of such activities is to recreate the lost image of a historical settlement, which should be considered as the first stage of investment in the fixed assets of a modern settlement and the creation of its new urban-

1. For the first time, the phrase 'urban planning culture' appeared in the book by E.A. Goldsamt and O.A. Shvidkovsky "The Urban Planning Culture of the European Socialist Countries" [2]. The authors gave the deepest definition of this phrase as a complex of social, material and spiritual (including artistic) values developed by society that arose during the formation of cities and other types of settlements, as well as a body of knowledge and ideas used in the process of creation of new and reconstruction of existing settlements based on the artistic tastes of the society and the material and technical capabilities and skills achieved by it. 
forming base. Today, we are trying to identify, preserve or recreate cities that, according to F.M. Dostoevsky, "no one dreamed even in a dream. Such cities, which appeared in the nineteenth century, have never been seen by the humankind before" [3].

\section{LANDMARKS}

The first published material where an attempt was made to reveal the essence of the concept of 'landmark' was the monograph "The Urban Planning of Landmarks. Basics of Planning" [4]. However, till nowadays, it is still difficult to resolve the issue of justifying the boundaries of the territory of such cultural heritage object (hereinafter - CHO) and its sphere of protection. Not less dangerous for landmarks is the problem of substantiating the types of their "usage and the establishment of urban planning regulations".

A landmark is, first of all, a space saturated with some meanings of the past, values of its environmental field; in relation to the entire urban development space or natural environment, it is a space where the genes of the past generations of the city prevail, where we enter into a dialogue with the past. In this very environment we come in touch with amazing intangible heritage - the genius loci.

The legislator has introduced several types of 'landmarks', some of which are poorly associated with the concept of "real estate object of cultural heritage". So, based on the literal reading of the law, "landmarks are creations by man, or joint creations by man and nature, including the places of traditional existence of folk arts and crafts; centres of historical settlements or fragments of urban planning and development; memorable places, cultural and natural landscapes associated with the history of the formation of peoples and other ethnic communities on the territory of the Russian Federation, historical (including military) events, the life of prominent historical figures; archaeological heritage sites; places of worship; burial places of victims of mass repressions; religious and historical places" [5].

Of all the listed types of landmarks, the greatest difficulty is in identifying and fixing the boundaries of such real estate objects, represented with places of traditional existence of folk arts and crafts; memorable places, cultural and natural landscapes associated with the history of the formation of peoples and other ethnic communities on the territory of the Russian Federation; places of worship; religious and historical sites. But such objects of cultural heritage as "burial places of victims of mass repressions" should be recognized as completely unacceptable. It is for these types of landmarks the predominant criterion of value should be defined as their "intangible reality".

Let us turn to such 'landmarks' as "memorable places, cultural landscapes associated with the history of the formation of peoples and other ethnic communities on the territory of the Russian Federation". The complexity of the formula is due to the inter-sectoral nature of the given $\mathrm{CHO}$ and the vagueness of the terms introduced into the concepts, such as 'place' and 'cultural landscape', where "the formation of peoples and other ethnic communities" took place. Demographers, ethnographers and ethnologists, philosophers, sociologists, etc. are engaged in the study of the history of the origin of peoples and ethnic groups, and, therefore, when justifying this type of 'landmarks', various specialists are to define the boundaries of certain territory of a chosen landmark of that type. Regarding this type of landmark, one should determine a possible object of protection as an inalienable proof of the existence of landmark as a real estate object. But the answer to the question "what is the object of protection of this type of landmark" lies in the plane of the concepts of 'ethnos' and 'people'2. The characteristic features of ethnos that existed among the ancient Greeks, from whom the word originates, are the unity of the territory of residence, the presence of common historical past, a common language, culture, and mental peculiarities. These characteristics can be used for fixing the territories of certain landmarks, which are the real estate object only. At the same time, the object of protection should be recognized as intangible reality in the form of language, culture, and a common historical past. In 2013, in the article "People. Ethnos. Nation", its author Yu.I. Semenov considered that only after understanding the concepts of 'society' and 'community' one can get an answer to the question of the difference between the concepts of 'people' and 'ethnos' [6]. The discussion continues today. In this regard, the entire territory of the Russian Federation can be recognized as a landmark, since over the centuries there have been processes of formation of peoples

2. Ethnos (Greek $\check{\varepsilon} \theta v o \varsigma$ - people) — in some theories of ethnicity, a historically stable group of people united with common objective and subjective characteristics, including origin, common language, culture, economics, territory of residence, self-identification, outlook... the list may vary in the lists of different authors. 
and ethnic groups, including those through assimilation of various ethnic groups, adaptation of cultures and, consequently, the formation of new ones.

The peoples living on these territories now, perhaps, are descendants of Cimmerians, Scythians, and Sarmatians, or some other peoples, once inhabited the territory of the country. There are not only landscapes and natural wonders, but also historical settlements - and this fact makes the territory in general a unique $\mathrm{CHO}$ of the landmark type of "memorable places, cultural landscapes associated with the history of the formation of peoples and other ethnic communities on the territory of the Russian Federation". But a comprehensive answer for defining of the reliable boundaries of such landmark can be obtained on the basis of data on ethnogenesis and ethnic geography. In fact, we should talk about identifying an object of intangible heritage - and with it we would be able to establish the boundaries of a certain real estate $\mathrm{CHO}$ - a landmark.

\section{CONCLUSION}

Noteworthy, the problems of identifying 'historical settlement' and 'landmark' are closely connected with the most complicated problem of shaping the very essence of preservation - not material one, but the deepest, factual essence of the object of interest in the sphere of cultural heritage, whether it is a 'landmark' or a 'historical settlement'; this essence allows us to identify ourselves with past generations and the historical past of the country. This is the main aim of preserving our heritage - establishing a connection between the past, the previous community which passed away and the present, our generation and our descendants, whom we are to leave the real trace and memory. Today, it is necessary to change paradigm of the preservation of objects based on the idea of keeping the real estate objects of heritage only. Such approach can lead us to the complete lost of numerous objects of intangible culture and deprive us the chance of selfidentification.

\section{AUTHORS' CONTRIBUTIONS}

This article is independently completed by Eleonora Shevtchenko.

\section{REFERENCES}

[1] E.A. Shevchenko (ed.), Methodological recommendations for assessing the historical and cultural value of the settlement. Application of criteria of historical and cultural value of a settlement in the assessment of real estate located within the boundaries of a historical settlement (Metodicheskie rekomendatsii otsenki istoriko-kul'turnoi tsennosti poseleniia. Primenenie kriteriev istoriko-kul'turnoi tsennosti poseleniia $\mathrm{v}$ otsenke nedvizhimosti, raspolozhennoi $\mathrm{V}$ granitsakh istoricheskogo poseleniia). Sankt-Petersburg, Zodchii, 2014 [in Russian].

[2] E.A. Goldzamt, O.A. Shvidkovskiy, Urban culture of European Socialist Countries (Gradostroitel'naia kul'tura evropeiskikh sotsialisticheskikh stran). Moscow, Stroyizdat, 1985 [in Russian].

[3] F.M. Dostoyevsky, Collected works: in 15 vols., vol. 13 (Sobranie sochinenii: v 15 t., t. 13). Leningrad, Science (Nauka), 1994, pp. 264-268 [in Russian].

[4] Yu.V. Alekseyev, G.Yu. Somov, E.A. Shevchenko, Urban Planning of Landmarks: in 2 vol., vol. 1, Basics of Planning (Gradostroitel'noye planirovanie dostoprimechatel'nykh mest: osnovy planirovaniia: $\quad$ v 2 t., t. 1, Osnovy planirovaniia). Moscow, ASV, 2012 [in Russian].

[5] Federal Law No. 73-FZ of June 25, 2002 "On Objects of Cultural Heritage (Historical and Cultural Monuments) of the Peoples of the Russian Federation", changed and added, Article 3 (Federal'nyi zakon ot 25 iiunia 2002 g. $\quad \mathrm{N}$ 73-FZ "Ob ob"ektakh kul'turnogo naslediia (pamiatnikakh istorii i kul'tury) narodov Rossiiskoi Federatsii", ispravlennyi i dopolnennyi, Stat'ia 3), in: Rossiyskaya Gazeta: official website. URL: https://rg.ru/2002/06/29/pamjatniki-dok.html [in Russian].

[6] Iu.I. Semenov, People. Ethnic group. The nation. Article 1. Society, population, ethnic group (Narod. Etnos. Natsiia. Stat'ia 1. Obshchestvo, naselenie, etnos), in: Philosophy and Society (Filosofiya i obshchestvo), no. 1 (69), 2013, pp. 21-55. URL: https://www.socionauki.ru/journal/articles/153 057/ [in Russian]. 